Jurnal J-Ensitec: Vol 04|No. 01, November 2017

\title{
INOVASI MODEL PEMBELAJARAN PROBLEM BASED LEARNING DENGAN VISUALISASI VIRTUAL UNTUK MENINGKATKAN KETERAMPILAN PROSES SAINS
}

\author{
Eidelweis Dewi Jannati ${ }^{1)}$, Lia Milana ${ }^{2)}$ \\ Program Studi Teknik Mesin, Fakultas Teknik, Universitas Majalengka ${ }^{1)}$ \\ Email : eidelweis_unma@yahoo.com \\ Program Studi Teknik Industri,Fakultas Teknik, Universitas Majalengka ${ }^{2)}$ \\ Email : milanalia888@yahoo.co.id
}

\begin{abstract}
In government regulation of the republic of indonesia No. 19), article 26, paragraph 4, about the purpose of higher education which is said to prepare learners to be a society that: 1) possesses noble, 2) possesses knowledge, 3) skilled, 4) Independent, 5) Able to discover, develop, and apply science, technology, and useful art.It can be realized by applying the right learning model. Problem-based learning model with virtual visualization is one of the right alternative, because students are required to be active and creative in building their knowledge. The purpose of this research is to know the improvement of students' science process skill after applied model of problem based learning with virtual simulation. This research was conducted by quasi experimental method with one group pretest-posttest research design, IA industry technique as experiment class. The results: 1) students science process skills are increasing, The average normalized $N$-Gain score of 0.72 students' science process skills is included in the high category; 2) Students give positive responses to the application of Problem Based Learning Model with virtual visualization on Measurement materials.
\end{abstract}

Keywords: Problem Based Learning Model, Virtual Visualization, Processing Skills Science.

\section{PENDAHULUAN}

\subsection{Latar Belakang Masalah}

Dalam Peraturan Pemerintah No. 33 Tahun 1990, disebutkan tentang tujuan perguruan tinggi adalah menyiapkan peserta didik menjadi anggota masyarakat yang memiliki kemampuan akademik dan atau profesional yang dapat menerapkan, mengembangkan dan menyebarluaskan ilmu pengetahuan dan kesenian serta menyumbangkan untuk meningkatkan taraf kehidupan masyarakat dan memperkaya kehidupan nasional. Salah satu perguruan tinggi di majalengka terdapat program studi teknik Industri. Dalam kegiatan pembelajarannya disiapkan agar mahasiswa memiliki kemampuan dan keterampilan dalam mengaplikasikan hasil pembelajaran dalam kehidupan sehari-hari.

Salah satu matakuliah dasar di teknik Industri yaitu Fisika Dasar. Tujuan diberikan mata kuliah ini adalah memberikan wawasan tentang fisika sebagai landasan perkembangan ilmu dan teknologi, melalui pengajaran konsep dasar serta proses ilmiah fisika, agar dapat menunjang pengembangan pada mata kuliah lain selanjutnya. Namun keabstrakan konsep
Fisika membuat mahasiswa beranggapan bahwa Fisika sulit dipahami.

Berdasarkan observasi di prodi Teknik Industri semester 1 tahun ajaran 2015-2016, diperoleh hasil nilai akhir rata-rata 50, 43. Dengan demikian dapat dikatakan bahwa pemahaman konsep mahasiswa masih tergolong rendah. Hal ini disebabkan mahasiswa saatpembelajaran di kelas hanya mendengarkan dosen mengajar, mengerjakan soalsoal yang diberikan oleh dosen. Dengan demikian, mahasiswa belajar lebih pasif dan Keterampilan Proses Sains (KPS) mahasiswa yang masih tergolong rendah. Hal ini terlihat saat melakukan percobaan atau eksperimen, mahasiswa sangat ketergantungan pada dosen. Peran dosen lebih mendominasi, mahasiswa cenderung pasif sehingga mereka tidak terampil dalam menyelesaikan masalah-masalah riil.

Berdasarkan hasil wawancara studi pendahuluan dengan dosen fisika diperoleh hasil bahwa model pembelajaran yang biasa diterapkan ialah model konvensional dimana dosen lebih banyak menggunakan teknik ceramah serta menekankan pada latihan pemecahan soal. Model tersebut tidak melatihkan keterampilan proses sains dan pemahaman 
konsep. Padahal, pembelajaran sains akan bermakna dan bermanfaat apabila mahasiswa memiliki keterampilan proses sains agar dapat memecahkan permasalahan dalam kehidupan sehari-hari.

Salah satu model pembelajaran yang mendukung untuk menyelesaikan permasalahan diatas yaitu model pembelajaran problem based learning $(P B L)$. " $P B L$ adalah suatu pendekatan pembelajaran dengan membuat konfrontasi kepada pebelajar dengan masalah-masalah praktis atau pembelajaran yang dimulai dengan pemberian masalah dan memiliki konteks dengan dunia nyata" (Tan dalam Gunantara, 2014).Pengertian PBL menurut Dutch (dalam Gunantara, 2014) adalah "metode intruksional yang menantang peserta didik agar belajar untuk belajar bekerjasama dalam kelompok untuk mencari solusi bagi masalah yang nyata". Sedangkan Menurut Gunantara "Model Problem Based Learning merupakan model pembelajaran yang melibatkan siswa dalam memecahkan masalah nyata. Model ini menyebabkan motivasi dan rasa ingin tahu menjadi meningkat. Model PBL juga menjadi wadah bagi siswa untuk dapat mengembangkan cara berpikir kritis dan keterampilan berpikir yang lebih tinggi." Sementara Menurut Arends (dalam Juliawan, 2012), pembelajaran berbasis masalah adalah suatu model pembelajaran dengan pendekatan pembelajaran peserta didik pada masalah autentik peserta didik dapat menyusun pengetahuannya sendiri, menumbuhkembangkan keterampilan yang lebih tinggi, inkuiri dan memandirikan peserta didik".

Jadi dapat disimpulkan bahwa Model Problem Based Learning adalah model pembelajaran yang melibatkan mahasiswa dalam memecahkan masalah nyata baik secara kelompok maupun individu. Sehingga, rasa ingin tahu mahasiswa meningkat dan mereka turut aktif dalam pembelajaran. Hal ini menimbulkan keterampilan proses sain mahasiswa akan terlatih.

Beberapa penelitian yang relevan menunjukkan adanya peningkatan hasil belajar dari segi kognitif, psikomotorik (keterampilan proses sains mahasiswa), dan afektif (sikap ilmiah) adalah penelitian oleh Subagyo, dkk (2009) tentang pembelajaran dengan keterampilan proses sains untuk meningkatkan pengetahuan konsep suhu dan pemuaiaan. Penelitian oleh Rusmiyati dan Yulianto (2009) tentang peningkatan keterampilan proses sains dengan menerapkan model Problem Based-Instruction menunjukkan adanya peningkatan keterampilan proses sains yang mulai tumbuh dan terbentuk dari siklus pertama hingga ketiga, dan pemahaman materi yang diperoleh siswa dari hasil penerapan PBI telah mencapai ketuntasan klaksikal.

Untuk itu, peneliti bermaksud menerapkan suatu model pembelajaran yang melibatkan mahasiswa untuk melatih keterampilan proses sains melalui model pembelajaran pembelajaran problem based learning dengan visualisai virtual pada konsep Pengukuran. Visualisai virtual ditujukan untuk menarik perhatian mahasiswa seiring dengan kemajuan IPTEK. Salah satu konsep Fisika Dasar I di Prodi Teknik Industri adalah Pengukuran. Konsep Pengukuran berkaitan erat dengan kehidupan seharihari mahasiswa dan sering mereka gunakan dalam keseharian ataupun dalam kegiatan-kegiatan tertentu.

Berdasarkan latar belakang masalah yang telah dikemukakan diatas maka dapat disusun permasalahan penelitian sebagai berikut:

1) Bagaimanakah peningkatan keterampilan proses sains mahasiswa setelah diterapkan model pembelajaran problem based learning dengan visualisasi virtual pada materi pengukuran?

2) Bagaimana tanggapan mahasiswa terhadap model pembelajaran problem based learning dengan visualisasi virtual?

\subsection{TujuanPenelitian}

Berdasarkan rumusan masalah diatas, tujuan dari penelitian ini adalah untuk mengetahui:

1) Gambaran keterampilan proses sains mahasiswa dengan menerapkan model pembelajaran problem based learningdengan visualisasi virtualpada konsep Pengukuran.

2) Tanggapan mahasiswa terhadap proses pembelajaran problem based learning dengan visualisasi virtual.

\section{METODE PENELITIAN}

Penelitian ini dilakukan dengan metode quasi eksperimen (eksperimen semu) dengan desain penelitian one group pretest-posttes. Seperti pada tabel 1.

Tabel 1. Desain Penelitian

\begin{tabular}{ccc}
\hline Pretest & Perlakuan & Postest \\
\hline $\mathrm{T}_{1}$ & $\mathrm{X}_{1}$ & $\mathrm{~T}_{2}$ \\
\hline
\end{tabular}

Panggabean dalam Karsiah (2008)

Keterangan: $\quad \mathrm{T}_{1}=$ Pretest 


$$
\begin{aligned}
\mathrm{X}_{1}= & \begin{array}{l}
\text { Pembelajaran dengan } \\
\text { menerapkanmodel } \\
\text { pembelajaran problem based } \\
\text { learning }
\end{array} \\
\mathrm{T}_{2}= & \text { Postest }
\end{aligned}
$$

Model pembelajaran yang diterapkan yaitu model pembelajaran berbasis masalah dengan simulasi virtual. Lokasi penelitian di program studi Teknik Industri Universitas Majalengka.

\begin{tabular}{|c|c|c|}
\hline Jenis Data & $\begin{array}{c}\text { Teknik } \\
\text { Pengumpulan } \\
\text { Data }\end{array}$ & Keterangan \\
\hline $\begin{array}{l}\text { Keterlaksanaan } \\
\text { model } \\
\text { pembelajaran } \\
\text { problem based } \\
\text { learning }\end{array}$ & $\begin{array}{l}\text { Lembar } \\
\text { Pengamatan } \\
\text { Keterlaksanaan } \\
\text { Model } \\
\text { Pembelajaran } \\
\text { based learning }\end{array}$ & $\begin{array}{l}\text { Dilakukan } \\
\text { saat } \\
\text { pembelajaran }\end{array}$ \\
\hline $\begin{array}{l}\text { Tanggapan } \\
\text { terhadap model } \\
\text { pembelajaran }\end{array}$ & Tes skala sikap & $\begin{array}{l}\text { Dilakukan } \\
\text { setelah } \\
\text { pembelajaran }\end{array}$ \\
\hline
\end{tabular}

\subsection{Teknik Pengumpulan Data}

Berikut ini adalah tabel teknik pengumpulan data penelitian:

Tabel 2. Teknik pengumpulan data

\subsection{Teknik Analisis Data}

1) Menghitung gain yaitu perbandingan skor pretest dan posttest

$$
G=T_{2}-T_{1}
$$

Keterangan:

$G$ = gain

$T_{1}=$ skor pretest

$T_{2}=$ skor posttest

2) Menghitung gain ternormalisasi, yaitu perbandingan dari skor gain aktual dengan skor gain maksimum, dengan rumus sebagai berikut:

$$
N G=\frac{\text { skor postes }- \text { skor pretes }}{\text { skormax }- \text { skor pretes }}
$$

(Meltzer dalam Herlanti, 2006)

Tabel 3. Kategori Tafsiran NG

\begin{tabular}{cc}
\hline Nilai NG & Kriteria \\
\hline $0,00-0,30$ & Rendah \\
$0,31-0,70$ & Sedang \\
$0,71-1$ & Tinggi \\
\hline
\end{tabular}

3) Uji Normalitas

Melakukan uji normalitas data yang diperoleh dari data pretes dan postes dengan menggunakan rumus :

$$
\chi^{2}=\sum \frac{(O i-E i)^{2}}{E i}
$$

(Subana, 2000)

Keterangan :

$$
\begin{array}{ll}
\chi^{2} & =\text { Chi Kuadrat } \\
O i & =\text { Frekuensi Observasi } \\
E i & =\text { Frekuensi Ekspektasi }
\end{array}
$$

4) Uji Hipotesis

a. Apabila data berdistribusi normal maka digunakan statistik parametris yaitu dengan menggunakan uji " $t$ ". Adapun langkah-langkahnya adalah sebagai berikut:

- Menghitung harga $t_{\text {hitung }}$ menggunakan rumus:

$$
t_{\text {hitung }}=\frac{M d}{\sqrt{\frac{\sum \mathrm{d}^{2}-\frac{\left(\sum \mathrm{d}\right)^{2}}{\mathrm{n}}}{\mathrm{n} \cdot(\mathrm{n}-1)}}}
$$

$M d=$ Nilai rata-rata hitung dari beda/selisih antara skor pretest dan postest

$d$ merupakan gain

$n$ merupakan jumlah subjek

- $t_{\text {tabel }}$ berpegang pada derajat kebebasan $(\mathrm{db})=\mathrm{N}-1$ yang telah diperoleh, baik pada taraf signifikansi $1 \%$ ataupun $5 \%$.

- Jika $t_{\text {hitung }} \geq t_{\text {tabel }}$ maka Ho ditolak sebaliknya Ha diterima berarti terdapat peningkatan keterampilan proses sains dan pemahaman konsep siswa secara signifikan.Jika $t_{\text {hitung }}$ $\leq \mathrm{t}_{\text {tabel }}$ maka Ho diterima dan $\mathrm{Ha}$ ditolak yang berarti tidak terdapat peningkatan keterampilan proses sains dan pemahaman konsep siswa secara signifikan.

(Sudijono, 1999)

b. Apabila data terdistribusi tidak normal maka dilakukan dengan uji wilcoxonmacth pairs test 


$$
z=\frac{T-\mu_{T}}{\sigma_{T}}=\frac{T-\frac{n(n+1)}{4}}{\sqrt{\frac{n(n+1)(2 n+1)}{24}}}
$$

Kriteria

$\mathrm{Z}_{\text {hitung }}>\mathrm{Z}_{\text {tabel }}$ maka $\mathrm{H}_{0}$ ditolak, $\mathrm{H}_{\mathrm{a}}$ diterima

$\mathrm{Z}_{\text {hitung }}<$ Ztabel maka $\mathrm{H}_{0}$ diterima, $\mathrm{H}_{\mathrm{a}}$ ditolak

(Sugiyono, 2006)

\subsection{Analisis Proses Pembelajaran Problem Based Learning}

Mengubah jumlah skor yang telah diperoleh menjadi nilai persentase dengan menggunakan rumus:

$$
N P=\frac{R}{S M} \times 100 \%
$$

Keterangan:

$N P$ : Nilai persen aktivitas dosen yang dicari atau yang diharapkan

$R \quad$ : Jumlah skor yang diperoleh

$S M$ : Skor maksimum ideal

100 : Bilangan tetap

Tabel 4. Kriteria aktivitas dosen dalam pembelajaran Problem Based Learning

\begin{tabular}{cc}
\hline Nilai (\%) & Kategori \\
\hline $86 \%-100$ & Sangat baik \\
$76 \%-85$ & Baik \\
$60 \%-75$ & Sedang \\
$55 \%-59$ & Kurang \\
$\leq 57$ & Sangat Kurang \\
\hline
\end{tabular}

\subsection{Menghitung Presentase Keterlaksanaan Pembelajaran}

- Menghitung Persentase Sikap Mahasiswa

Angket ini menggunakan skala Likert, setiap mahasiswa diminta untuk menjawab suatu pernyataaan dengan jawaban Sangat Setuju (SS), Setuju (S), Tidak Setuju (TS), dan Sangat Tidak Setuju (STS). Untuk pernyataan positif maka dikaitkan dengan nilai $\mathrm{SS}=4, \mathrm{~S}=3$, TS $=2$ dan STS $=1$, dan sebaliknya (Sujana, 1989). Angket yang digunakan dalam penelitian ini terdiri dari 14 pernyataan. Dengan demikian skor maksimal yang dapat dicapai oleh mahasiswa adalah 56 dan minimal 14. Skor antara 42 (diperoleh dari nilai $S$ $\mathrm{x}$ jumlah pernyataan) sampai 56 (diperoleh dari nilai SS x jumlah pernyataan) dinyatakan positif
Jurnal J-Ensitec: Vol 04|No. 01, November 2017

dan skor antara 14 (diperoleh dari nilai STS x jumlah pernyataan) sampai 28 (diperoleh dari nilai TS x jumlah pernyataan) dinyatakan negatif. Skor dari setiap pernyataan untuk seluruh mahasiswa dirata-ratakan dan dinyatakan dalam bentuk persentase capaian dengan menggunakan persamaan:

$$
\% S=\frac{\bar{s}}{S m} x 100 \%
$$

Dimana:

$$
\begin{aligned}
& \bar{S}=\text { skor rata-rata } \\
& S_{m}=\text { skor maksimum }
\end{aligned}
$$

Dalam penelitian ini, penulis hanya ingin mengetahui persentase sikap mahasiswa (positif dan negatif) terhadap pembelajaran dengan model pembelajaran.

\section{HASIL PENELITIAN DAN PEMBAHASAN}

3.1. Peningkatan Keterampilan Proses Sains

Materi kuliah yang diberikan pada pertemuan ke-1 yaitu mengenai pengukuran panjang pertemuan ke-2 yaitu mengenai pengukuran massa, dan pada pertemuan ke-3 materi yang disampaikan adalah mengenai pengukuran waktu dan volume benda yang tidak beraturan.

Untuk mengetahui keterampilan proses sains mahasiswa, maka diberikan tes berupa soal pilihan ganda yang berjumlah 18 butir soal. Tes ini diberikan sebelum (pretest) dan sesudah (posttest) model Problem Based Learning dengan Visualisasi Virtual diterapkan.

Hasil pretest dan posttest selanjutnya dilakukan uji normalitas untuk mengetahui apakah data berdistribusi normal atau tidak dengan menggunakan chi kuadrad $\left(\chi^{2}\right)$. Kriteria pengujiannya adalah:

4. Jika $\chi_{\text {hitumg }}^{2}<\chi_{\text {tabel }}^{2}$, maka distribusi normal

5. Jika $\chi_{\text {hitumg }}^{2}>\chi_{\text {tabel }}^{2}$, maka distribusi tidak normal.

Hasil pengujian normalitas tersebut diperlihatkan pada tabel 1 .

Tabel 5. Hasil Uji Normalitas Pretest dan Postest

\begin{tabular}{llll}
\hline Hasil & Nilai & Nilai & \\
Soal & $\chi_{\text {hitung }}^{2}$ & $\chi_{\text {tabel }}^{2}$ & Keterangan \\
\hline Pretes & 2,15 & 11,07 & Normal \\
Postes & 4,3 & 11,07 & Normal \\
\hline
\end{tabular}


Karena sebaran data pretes dan postes semuanya berdistribusi normal, maka selanjutnya dilakukan uji $t$ dengan menggunakan taraf signifikansi 5\% dengan kriteria sebagai berikut:

- Jika - $t_{\text {tabel }}<t_{\text {hitung }}<t_{\text {tabel }}$ maka tidak terdapat perbedaan secara signifikan.

- Jika $t_{\text {hitung }}>t_{\text {tabel }}$ atau $t_{\text {hitung }}<-t_{\text {tabel }}$ maka terdapat perbedaan yang signifikan.

Hasil perhitungan diperoleh bahwa nilai $t_{\text {hitung }}$ adalah 24,604 dan nilai $t_{\text {tabel }}$ adalah2,756. Data ini menunjukkan bahwa 24,604>2,756 atau $t_{\text {hitung }}>t_{\text {tabel }}$ yang berarti bahwa Ha diterima, yaitu terdapat perbedaan yang signifikan hasil Keterampilan Proses Sains Mahasiswa setelah menerapkan model Problem Based Learning dengan Visualisasi Virtual pada materi pengukuran.

Berdasarkan data skor pretest dan posttest sains seperti tercantum pada tabel dibawah ini:

Tabel 6. Rata-rata Keterampilan Proses Sains

\begin{tabular}{ccc}
\multicolumn{3}{c}{ Mahasiswa } \\
\hline $\begin{array}{c}\text { Rata-rata Skor } \\
\text { Pretest }\end{array}$ & $\begin{array}{c}\text { Rata-rata Skor } \\
\text { Postest }\end{array}$ & NGain \\
\hline 31 & 81 & 0,72 \\
\hline
\end{tabular}

Apabila tabel diatas untuk data pretest dan posttest, disajikan kedalamdiagram, diperoleh hasil sebagai berikut:

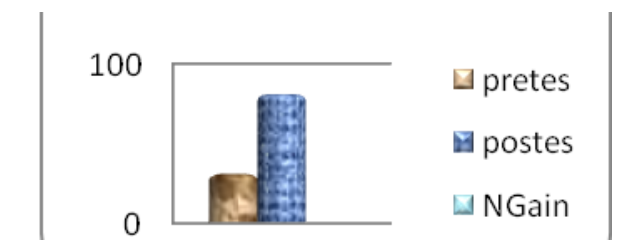

Gambar 1. Grafik Skor Rata-rata Tes Keterampilan

Proses Sains Mahasiswa

Pada tabel diagram diatas terlihat rata-rata skor pretes Keterampilan Proses Sains Mahasiswa masih rendah, ini menunjukkan bahwa sebelum pembelajaran mahasiswa belum memahami materi kuliah, dan setelah diberi perlakuan hasil tes Keterampilan Proses Sains Mahasiswa meningkat. Kemudian apabila skor rata-rata pretes dengen postes kita bandingkan, diperoleh rata-rata pretes $31<$ ratarata postes 81 dengan skor maksimal 100. Maka berdasarkan data tersebut terdapat perbedaan yang signifikan antara rata-rata pretes dan postes.

Jika hasil pretest ini dibandingkan dengan hasil postest maka dikatakan terdapat peningkatan Keterampilan Proses Sains Mahasiswa dengan rata- rata 50 dari grafik di atas dapat diketahui bahwa indek gain Keterampialn Proses Sains sebesar 0,72 termasuk dalam kategori tinggi. Hal ini menunjukkan bahwa penerapan model Problem Based Learning dengan Visualisasi Virtual efektif untuk meningkatkan keterampilan proses sains mahasiswa.

Untuk mengetahui skor tiap aspek Keterampilan Proses Sains ditunjukkan oleh tabel berikut ini:

Tabel 7. Rata-rata Tiap Aspek Keterampilan Proses

\begin{tabular}{|c|c|c|c|}
\hline \multicolumn{4}{|c|}{ Sains } \\
\hline \multirow{2}{*}{ Aspek KPS } & \multicolumn{2}{|c|}{ Skor rata-rata } & \multirow{2}{*}{ Ngain } \\
\hline & Pretest & Postest & \\
\hline Observasi & 37 & 78 & 0,65 \\
\hline Mengkasifikasikan & 26 & 73 & 0,64 \\
\hline Merencanakan & & & \\
\hline Percobaan & 28 & 82 & 0,75 \\
\hline Menggunakan & & & \\
\hline Alat & 31 & 89 & \\
\hline Pengukuran & & & 0,84 \\
\hline Berkomunikasi & 38 & 83 & 0,73 \\
\hline Menerapkan & 29 & 79 & \\
\hline Konsep & & & 0,70 \\
\hline
\end{tabular}

Pada tabel dan diagram di atas terlihat rata-rata skor pretest pada tiap aspek Keteraampilan Proses Mahasiswa masih rendah, ini menunjukkan bahwa sebelum pembelajaran mahasiswa belum terbiasa untuk melakukan observasi, mengklasifikasikan, perencanaan percobaan, menggunakan alat dan pengukuran, berkomunikasi dan menerapkan konsep. Kemudian apabila skor rata-rata pretes dengan postes kita bandingkan, diperoleh rata-rata pretes pada aspek observasi adalah $37<$ dari rata-rata postes yaitu 78 dengan skor maksimal 100, aspek mengklasifikasikan diperoleh rata-rata pretes adalah $26<$ dari rata-rata postes yaitu 73 dengan skor maksimal 100, aspek merencanakan percobaan diperoleh rata-rata pretes adalah $28<$ dari rata-rata postes yaitu 82 dengan skor maksimal 100, aspek menggunakan alat dan pengukuran diperoleh rata-rata pretes adalah $31<$ dari rata-rata postes yaitu 89 dengan skor maksimal 100 , aspek berkomunikasi diperoleh rata-rata pretes adalah $38<$ dari rata-rata postes yaitu 83 dengan skor maksimal 100, dan aspek menerapkan konsep diperoleh rata-rata pretes adalah 29 < dari rata-rata postes yaitu 79 dengan skor maksimal 100. Maka berdasarkan data tersebut terdapat peningkatan pada tiap aspek Keterampilan Proses Sains setelah pembelajaran. 
Peningkatan Keterampilan Proses Sains pada aspek observasi mengalami peningkatan dengan skor rata-rata yaitu sebesar 41 aspek ini dilatihkan melalui penggunaan alat inderanya seperti penglihatan dan peraba. Pada aspek mengklasifikasikan diperoleh peningkatan sebesar 47 pada aspek ini dilatih untuk dapat mengelompokkan, sebagai contoh mahasiswa dituntut untuk dapat mengelompokkan benda dengan alat ukurnya yang tepat. Pada aspek merencanakan percobaan diperoleh peningkatan sebesar 54 pada aspek ini siswa merencanakan percobaan dengan tujuan, alat dan bahan percobaan yang telah tersedia. Menggunakan alat dan penggukuran diperoleh peningkatan sebesar 58, mahasiswa menentukan alat dan pengukuran yang diperlukan dalam suatu penyelidikan, contohnya: menggunakan gelas ukur untuk menentukan volume suatu benda yang tidak beraturan, menggunakan jangka sorong untuk mengukur diameter suatu benda. Pada aspek berkomunikasi diperoleh peningkatan sebesar 45, pada aspek ini mahasiswa belajar untuk berbicara di depan kelas, mengemukakan pendapat dengan melakukan diskusi antar kelompok dan mempresentasikan hasil percobaannya di depan kelas. Pada aspek menerapkan konsep mengalami peningkatan sebesar 50, pada aspek ini mahasiswa diberikan latihan-latihan untuk menerapkan konsep yang telah mereka pelajari. Indeks gain pada ke-6 aspek Keterampilan Proses Sains menunjukan kategori tinggi, artinya model Problem Based Learning dengan Visualisasi Virtual sangat efektif untuk meningkatkan Keterampilan Proses Sains Mahasiswa.

\subsection{Tanggapan Mahasiswa Terhadap Model Pembelajaran Problem Based Learning dengan Visualisasi Virtual}

Berdasarkan hasil analisis angket tanggapan mahasiswa terhadap model pembelajaran Problem Based Learning dengan Visualisasi Virtual, dapat disimpulkan bahwa mahasiswa memberikan tanggapan positip terhadap model pembelajaran Problem Based Learning dengan Visualisasi Virtual yang diterapkan pada pembelajaran konsep Pengukuran. Berdasarkan data yang diperoleh, sebesar $80 \%$ mahasiswa menyatakan setuju bahwa model pembelajaran experiential Kolb yang digunakan adalah model pembelajaran baru, $82 \%$ mahasiswa menyatakan bahwa cara dosen bertanya dapat memotivasi mahasiswa dalam mencari tahu jawaban, 83\% mahasiswa menyatakan bahwa kegiatan diskusi membuat mahasiswa lebih lebih menghargai pendapat orang lain. Sebesar $37 \%$ mahasiswa merasa model pembelajaran yang digunakan sama dengan model yang digunakan pada model pembelajaran sebelumnya, $40 \%$ mahasiswa menyatakan model pembejalaran Problem Based Learning dengan Visualisasi Virtual yang diterapkan membuat sulit dalam memahami konsep dan $38 \%$ menyatakan bahwa pembelajaran secara keseluruhan sangat membosankan.

Angket diberikankepada mahasiswa bertujuan untuk mengetahui tanggapan mahasiswa terhadap penerapan model Pembelajaran Berbasis Masalah. Angket ini terdiri dari 14 buah pernyataan dengan 4 kategori skor tanggapan. Untuk pernyataan positif kategori skornya yaitu Sangat Setuju (SS) dengan skor 4, Setuju (S) dengan skor 3, Tidak Setuju (TS) dengan skor 2 dan Sangat Tidak Setuju (STS) dengan skor 1. Sedangkan untuk pernyataan negatif, kategori skor tanggapannya adalah sebaliknya dari pernyataan positif. Angket ini diberikan pada kelas eksperimen diakhir pembelajaran.

Untuk mengetahui tanggapan mahasiswa terhadap pembelajaran dengan menggunakan model Pembelajaran Berbasis Masalah dapat dilihat tabel.

Tabel 8. Rekapitulasi hasil analisis angket tanggapan mahasiswa terhadap seluruh pernyataan

\begin{tabular}{|c|c|c|c|}
\hline Pernyataan & $\begin{array}{l}\text { Rata- } \\
\text { rata }\end{array}$ & $\begin{array}{l}\text { Rata- } \\
\text { rata } \\
(\%)\end{array}$ & Kategori \\
\hline $\begin{array}{l}\text { Persepsi mahasiswa } \\
\text { tentang model } \\
\text { Pembelajaran } \\
\text { Berbasis Masalah. }\end{array}$ & 9.17 & 76.4 & Setuju \\
\hline 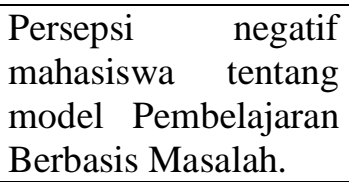 & 1.47 & $\begin{array}{l}36.6 \\
7\end{array}$ & $\begin{array}{l}\text { Tidak } \\
\text { Setuju }\end{array}$ \\
\hline $\begin{array}{l}\text { Ketertarikan } \\
\text { mahasiswa terhadap } \\
\text { model Pembelajaran } \\
\text { Berbasis Masalah. }\end{array}$ & $\begin{array}{l}15.7 \\
7\end{array}$ & $\begin{array}{l}78.8 \\
3\end{array}$ & Setuju \\
\hline $\begin{array}{l}\text { Ketidaktertarikan } \\
\text { mahasiswa terhadap } \\
\text { model Pembelajaran } \\
\text { Berbasis Masalah. }\end{array}$ & 1.50 & 37.5 & $\begin{array}{l}\text { Tidak } \\
\text { Setuju }\end{array}$ \\
\hline $\begin{array}{ll}\text { Motivasi } & \text { positif } \\
\text { mahasiswa } & \text { akibat } \\
\text { penerapan } & \text { model } \\
\text { Pembelajaran } & \end{array}$ & 8.87 & $\begin{array}{l}73.8 \\
8\end{array}$ & Setuju \\
\hline
\end{tabular}




\begin{tabular}{|c|c|c|c|}
\hline Pernyataan & $\begin{array}{l}\text { Rata- } \\
\text { rata }\end{array}$ & $\begin{array}{l}\text { Rata- } \\
\text { rata } \\
(\%)\end{array}$ & Kategori \\
\hline \multicolumn{4}{|l|}{ Berbasis Masalah. } \\
\hline $\begin{array}{lr}\text { Motivasi } & \text { negatif } \\
\text { mahasiswa } & \text { akibat } \\
\text { penerapan } & \text { model } \\
\text { Pembelajaran } & \\
\text { Berbasis Masalah. }\end{array}$ & 1.50 & 37.5 & $\begin{array}{l}\text { Tidak } \\
\text { Setuju }\end{array}$ \\
\hline & 6.40 & 48.70 & Setuju \\
\hline
\end{tabular}

Berdasarkan data pada Tabel 4.8 , sebesar $80 \%$ mahasiswa menyatakan setuju bahwa model Pembelajaran Berbasis Masalahyang digunakan adalah model pembelajaran baru, $82 \%$ mahasiswa menyatakan bahwa cara dosen bertanya dapat memotivasi mahasiswa dalam mencari tahu jawaban, 83\% mahasiswa menyatakan bahwa kegiatan diskusi membuat mahasiswa lebih menghargai pendapat orang lain. Sebesar 37\% mahasiswa merasa model pembelajaran yang digunakan sama dengan model yang digunakan pada model pembelajaran sebelumnya, $40 \%$ mahasiswa menyatakan model Pembelajaran Berbasis Masalahyang diterapkan membuat sulit dalam memahami konsep dan 38\% menyatakan bahwa pembelajaran secara keseluruhan sangat membosankan.

Model pembelajaran yang diterapkan menurut mahasiswa sangat menyenangkan sehingga mahasiswa menjadi lebih termotivasi untuk belajar dan menginginkan agar dapat diterapkan pada pembelajaran materi yang lain. Tahap-tahap pembelajaran Problem Based Learning dengan Visualisasi Virtual mampu menggali pemahaman konsep dan melatih keterampilan proses sains mahasiswa. Dengan demikian mahasiswa lebih termotivasi dalam belajar.

\section{KESIMPULAN DAN SARAN \\ 4.1. Kesimpulan}

Berdasarkan laporan kemajuan penelitian yang telah dilakukan tentang Inovasi Model Pembelajaran Problem Based Learning dengan Visualisasi Virtual untuk meningkatkan pemahaman konsep dan kemampuan keterampilan proses sains pada materi pengukuran dapat disimpulkan bahwa:

1. Inovasi Model Pembelajaran Problem Based Learning dengan Visualisasi Virtual dapat lebih meningkatkan Keterampilan Proses Sains mahasiswa dengan skor N-Gain 0,72 termasuk pada kategori tinggi.
2. Mahasiswa memberikan tanggapan positif sebesar $80 \%$ terhadap penerapan Inovasi Model Pembelajaran Problem Based Learning dengan Visualisasi Virtual pada materi Pengukuran.

\subsection{Saran}

Berdasarkan hasil penelitian yang telah
dilakukan tentang penerapan ModelPembelajaran Problem Based Learning dengan Visualisasi Virtual untuk meningkatkan pemahaman konsep dan Keterampilan Proses Sains Mahasiswa pada materi Pengukuran maka peneliti dapat memberikan saran sebagai berikut:

1. Inovasi Model Pembelajaran Problem Based Learning dengan Visualisasi Virtual merupakan model pembelajaran yang sangat jarang dilakukan dosen sehingga pada pertemuan awal pembelajaran sebaiknya dosen menjelaskan langkah-langkah kegiatannya secara keseluruhan, mempersiapkan alat instrumen dengan baik dan tepat agar dalam pembelajaran mahasiswa merasa terbiasa dan termotivasi dengan model pembelajaran ini.

2. Diperlukan persiapan yang matang dalam menerapkan Inovasi Model Pembelajaran Problem Based Learning dengan Visualisasi Virtual agar dalam penerapannya dapat menggunakan waktu semaksimal mungkin.

\section{REFERENSI}

Gunantara, GD.; Md Suarjana dan Pt. Nanci Riastini. 2014. Penerapan Model Pembelajaran Problem Based Learning Untuk Meningkatkan Kemampuan Pemecahan Masalah Matematika Siswa Kelas V. Jurnal Mimbar PGSD Universitas Pendidikan Ganesha Jurusan PGSD. Vol 2, No: 1,

Herlanti, Yani. 2006. Tanya Jawab Seputar Penelitian Pendidikan Sains. Jakarta: UIN Syarif Hidayatullah.

Juliawan, D. 2012. Pengaruh Model Pembelajaran Berbasis Masalah Terhadap Pemahaman Konsep dan Keterampilan Proses Sains Siswa Kelas XI IPA SMA Negeri 2 Kuta Tahun Pelajaran. 2011/2012. pasca.undiksha.ac.id/ejournal/index.php/jurnal_ipa/article/.../192.

Diakses 20 Mei 2016

Rusmiyati, A. and Yulianto, A. 2009. Peningkatan Keterampilan Proses Sains Dengan Menerapkan 
Jurnal J-Ensitec: Vol 04|No. 01, November 2017

Model Problem Based-Instruction. Jurnal Pendidikan Fisika Indonesia, 5(2).

Subagyo, Y. and Marwoto, P. 2009. Pembelajaran dengan Pendekatan Keterampilan Proses Sains untuk Meningkatkan Penguasaan Konsep Suhu dan Pemuaian. Jurnal Pendidikan Fisika Indonesia. 5(1).
Subana. 2000. Statistik Pendidikan. Bandung: Pustaka Setia.

Sugiyono. 2006. Metode Penelitian Kuantitatif, Kualitatif dan $R \& D$. Bandung:Alfabet

Sudijono, A. 1999. Pengantar Statistik Pendidikan. Jakarta. PT. Raja Grafindo Persada, 1999. 